19 Revue d'histoire du XIXe siècle

Société d'histoire de la révolution de 1848 et des

révolutions du XIXe siècle

18 | 1999

Varia

\title{
Les barricades provinciales : les Trois glorieuses de
} 1830

\section{Pamela Pilbeam}

\section{OpenEdition Journals}

Electronic version

URL: http://journals.openedition.org/rh19/148

DOI: $10.4000 /$ rh19.148

ISSN: 1777-5329

\section{Publisher}

La Société de 1848

\section{Printed version}

Date of publication: 1 June 1999

ISSN: 1265-1354

\section{Electronic reference}

Pamela Pilbeam, «Les barricades provinciales : les Trois glorieuses de 1830 », Revue d'histoire du XIXe siècle [Online], 18 | 1999, Online since 10 September 2008, connection on 19 April 2019. URL : http:// journals.openedition.org/rh19/148; DOI : 10.4000/rh19.148

This text was automatically generated on 19 April 2019.

Tous droits réservés 


\title{
Les barricades provinciales : les Trois glorieuses de 1830
}

\author{
Pamela Pilbeam
}

\section{ABSTRACTS}

Provincial barricades during the $\mathbf{1 8 3 0}$ revolution If Paris played a major part in the shift of regime, the provinces were ready to follow suit. In many départments, liberals anticipated the Parisian events; but quite often, they did come across any obstacle. Préfets preferred to preserve their career and carefully negotiated their withdrawal. If the judicial apparatus does not seem to have been very eager to maintain the authority of the Bourbons, the reactions of the army were more diverse. The military felt more threatened at the borders and in the towns where popular reactions were more violent. All of this favoured a rapid and efficient seizure of power by the liberals, who mostly had to canalise the hostility of the rioters towards the clergy as well as their economic claims.

Si Paris a joué un rôle majeur dans le changement de régime, la province n'a pas seulement été attentiste. Dans de nombreux départements les libéraux anticipent sur les événements parisiens mais souvent sans rencontrer d'obstacle. Les préfets préfèrent préserver leur carrière et négocient prudemment leur retrait. Si, en province, l'appareil judiciaire ne semble pas avoir été très soucieux de maintenir l'autorité des Bourbons, dans l'armée, les réactions furent plus variées. Le commandement militaire se sentait plus menacé aux frontières et dans les villes où les réactions populaires étaient plus violentes. Tout ceci favorisa une prise de pouvoir rapide et efficace par les libéraux qui eurent surtout à canaliser l'anticléricalisme des émeutiers et leurs revendications économiques. 
INDEX

Mots-clés: Trois glorieuses, Barricades, 1830 